\title{
PERSEPSI JEMAAT TERHADAP GAYA HIDUP PENDETA PEMINUM DAN PECANDU ROKOK DALAM HUBUNGANNYA DENGAN PELAYANANANNYA DI JEMAAT
}

Oleh:

\author{
NAYARPIN \\ Mahasiswa IAKN Toraja \\ Email: Nayarpin02@gmail.com
}

\begin{abstract}
ABSTRAK
Diera globalisasi banyak hal yang bisa membuat kepribadian seseorang menjadi buruk. Dan hal ini terkadang bisa terpengaruh pada gaya hidup yang seharusnya tidak dilakukan oleh seseorang. Hal yang lazim yang menjadi gaya hidup seseorang yang tidak seaharusnya dilakukan itu adalah seorang pendeta yang peminum dan pecandu rokok. Hal ini sangat berpengaruh pada tugasnya sebagai seorang pendeta. Dan dengan gaya hidup seperti itu menimbulkan persepsi yang tidak baik dari jemaat dan ini juga berpengaruh pada pertumbuhan spritualitas jemaat ketika pendeta tidak berprilaku baik. Sehingga dengan adanya penelitian ini diharapkan dapat mengubah pola pikir para pendeta untuk tidak lagi hidup dalam hal yang tidak sepantasnya ia lakukan. Di dalam 1 Kor. 6:19-20. Adalah peringatan kepada umat Allah untuk menyucikan tubuh dari hal-hal yang tidak benar sebab tubuh ini adalah bait Roh Kudus.
\end{abstract}

Kata Kunci: pendeta, jemaat, persepsi

\section{PENDAHULUAN}

Dunia di zaman ini boleh dikata dan memang, suda jauh dari zaman sebelumnya. Banyak hal yang muncul di jaman ini yang bisa membawa dampak positif kepada manusia tetapi ada juga hal yang berdampak negatif. Dan hal ini sangat berpengaruh kepada gaya hidup manusia itu sendiri. Dengan pengaruh ini bisa saja berdampak buruk dalam diri seseorang pun bisa juga berdampak baik. Tetapi tak dapat dipungkiri bahwa dengan jaman yang suda makin maju ini hal-hal yang baru muncul yang sebelumnya tidak perna ada sama sekali sangat berdampak buruk bagi kehidupan manusia. Terlebih berdampak buruk pada gaya hidupnya. Seperti halnya yang begitu cepat berkembang di jaman ini adalah teknologi. Dari perkembangan pesat dari teknologi tersebut banyak hal yang memunculkan mengenai 
variasi gaya hidup (life style). Dan hal ini berimbas atau dapat terpengaruh oleh gaya hidup masyarakat yang tid ak benar. ${ }^{1}$

Tetapi di tinjau di jaman ini tak hanya teknologi yang bisa berdampak buruk pada gaya hidup seseorang. Tetapi ada juga hal lain yang lebih berpengaruh baik pada kesehatan fisik pun akan gaya hidup seseorang dan juga di pengaruhi pada spiritulitas iman seseorang. Antara lain adalah mengkonsumsi minuman keras dan rokok. Kedua hal ini sangat memberikan dampak yang buruk pada gaya hidup seseorang dan lebih di pengaruhi oleh tugas dan tanggung jawab seseorang. Dan hal ini yang biasanya menjadi korban adalah anakanak muda. Tetapi ternyata tak hanya pada anak-anak muda. Kini juga yang menjadi korbannya adalah orang tua, dan lebih fatalnya lagi seorang pendeta jemaat. Dan ini sangat berpengaruh pada tugas tanggung jawabnya sebagai hamba Tuhan.

Sehingga hal ini banyak memunculkan persepsi warga jemaat kepada pendetanya yang tidak memberikan contoh gaya hidup yang baik. Akibatnya pula tugas pelayanan dari seorang pendeta tersebut jadi tidak maksimal lagi. Dan hal ini juga dapat memberikan dampak buruk pada jemaatnya sendiri. Sehingga dari masalah yang di alami oleh seorang pendeta tersebut, dengan penelitian ini dapat memberikan pemahaman kepada pedeta dan juga dapat mengubah pole gaya hidupnya. Dan juga dapat di ketahui bahwa seorang pedeta dengan gaya hidup tidak benar akan menimbulkan persepsi buruk dari jemaat.

Adapun beberapa penelitian sebelumnya mengenai gaya hidup ataralain: Model gaya hidup nazir sebagai refleksi gaya hidup hebon penghkotbah pada zaman milenial. ${ }^{2}$ dan pengaruh saat teduh dan ibadah terhadap pengambilan keputusan dalam memilih pasangan hidup. ${ }^{3}$ Dengan penelitian ini beranjak pada fokus judul besar sebagai sebua masalah, tentang bagaimana persepsi jemaat terhadap gaya hidup pendata peminum dan pecandu rokok dalam hubungannya dengan pelayanannya di jemaat.

\section{TUJUAN}

Tujuan dari penelitian ini adalah untuk mengetahui seperti apa persepsi jemaat terhadap gaya hidup seorang pendeta peminum dan pecandu rokok dalam hubungannya dengan pelayanannya. dan juga untuk mengetahui apa sebenarnya yang menjadi penyebab serta dampak dari gaya hidup pendeta tersebut.

\footnotetext{
${ }^{1}$ Haryono, T, and Daniel Fajar Panuntun. "Model Gaya Hidup Nazir Sebagai Refleksi Gaya Hidup Hedon Pengkotbah Pada Zaman Milenial.” Evangelikal: Jurnal Teologi Injili dan Pembinaan Warga Jemaat3, no. 2 (2019): 174

${ }^{2}$ Ibid

${ }^{3}$ Efi Nurwindayani and Daniel Fajar Panuntun, "Pengaruh Saat Teduh Dan Ibadah Terhadap Pengambilan Keputusan Dalam Memilih Pasangan Hidup,” FIDEI: Jurnal Teologi Sistematika Dan Praktika 2, no. 2 (2019)
} 


\section{MANFAAT}

Manfaat dari penelitian ini adalah untuk memberikan pemahaman kepada pendeta bahwa dengan gaya hidup yang yang tidak baik akan memberikan dampak buruk pada tugas pelayannya, dan terlebih memberi dampak buruk terhadap jemaat.

\section{PEMBAHASAN}

\section{Pendeta/Gembala dan Fungsinya dalam jemaat}

Dalam bahasa indonesia umumnya istilah pendeta digunakan untuk menyebut pemimpin dalam gereja-gereja protestan. sedangkan dalam bahasa sanskerta disebut sebagai pandita yang berakar dalam tradisi agama Hindu. Kata pandit dalam Hinduisme merupakan gelar anggota kasta Brahmana yang melakukan fungsi imamat, tetapi memiliki spesialisasi dalam mempelajari dan menafsirkan kitab suci dan teks-teks hukum serta filsafat kuno. Jadi kata pandit umumnya digunakan sebagai gelar seorang terpelajar atau seorang Imam. Sedangkan dalam bahasa asing di Barat sebutan untuk pendeta umumnya dikenal dengan nama Pastor (sebutan yang umumnya sering di gunakan dalam lingkungan Gereja Katolik untuk menyebt imam atau pemimpin jemaat). Istilah pastor (priest) digunankan bukan hanya kalangan gereja Katolik, melainkan juga kalangan gereja Protestan. menurut Gladden nama pastor diterjemahkan dari kata Yunani poimen yang artinya 'gembala' sebagai sebutan yang digunakan Tuhan Yesus sendiri menjelaskan kasihNya, “Akulah Gembala yang baik dan aku mengenal domba-dombaku dan domba-dombaku mengenal Aku, sebagai mana Bapa mengenal Aku dan Aku mengenal Bapa" (Yoh. 10:14-15). Arti daru Gembala disini merujuk pada kehormatan dan tugas. ${ }^{4}$ Sehingga dapat di simpulkan bahwa kata pendeta atau pandita atau juga pastor adalah sebutan nama jabatan atau kehormatan dan tugas dalam gereja, sekaligus sebagai pemimpin atau imam dalam gereja.

Pendeta bukan hanya sebagai profesi tetapi juga memiliki tugas dan fungsinya. Adapun fungsi pendeta/Gembala dalam Alkitab adalah jabatan imam, nabi, raja, dan gembala. Di dalam PL jebatan pendeta dikenal dengan fungsinya sebagai imam, raja, nabi, dan gembala. Dari beberapa fungsi pendeta diatas juga masih melekat pada seorang pendeta bahwa fungsi pendeta adalah sebagai pemimpin jemaat dalam bertugas untuk memberkati, memberitakan firman, dan mengatur kehidupan jemaat. Penekanan fungsi seorang pendeta juga di tegaskan oleh Tuhan Yesus dalam PB sebagai gembala yang baik. Dalam PL diketahui bahwa seorang imam atau nabi merupakan perantara Allah dengan umatNya atau JemaatNya sekaligus

\footnotetext{
${ }^{4}$ Robert P. Borrong, “Melayani Makin Sungguh”, Cet.-1; Gunung Mulia: Jakarta, 2016, hlm 15
} 
sebagai penunjuk arah pada jalan yang benar. ${ }^{5}$ Dan hal ini tak hanya pada ada pada zaman PL tetapi sampai pada zaman sekarang tugas dan fungsi imam pun masih tetap melekat dalam pada tugas dan tanggung jawab seorang pendeta, yang suda menjadi penunjuk, pengatur dan pemimpin sekaligus perantara Allah dengan umatNya. Menurut Darmawijaya, kata imam dalam bahasa Yunani hiereus menunjuk pada kesucian, hubungan khusus dengan yang ilahi, dan juga bertugas memberikan firman Allah, khususnya yang berkaitan dengan hukumhukum Allah. Sehingga dapat juga dikatakan bahwa seorang imam/pendeta merupakan orang yang suci dihadapan Allah dan memiliki hubungan yang khusus dengan Allah. ${ }^{6}$ Adapun panggilan pendeta adalah sesuatu yang bersifat sakral sekaligus misterius. Mengapa dikatakan sakral karena Allah yang memanggil adalah suci dan karena tugas panggilan, panggilan pendeta adalah tugas suci karena ia dipanggil menjadi pelayan Tuhan sendiri.

Di dalam 1 Samuel 6:11, diceritrakan bahwa Daud, sebelum menjadi raja, ia bekerja sebagai gembala. Dalam Mazmur 23 di sana Allah disebut sebagai gembala yang memelihara dombaNya, sehingga mereka tidak kekurangan suatu apapun. Begitu juga Yesus menyampaikan diriNya dengan seorang gembala yang baik, (Yoh. 10:11). Di dalam (Yoh. 21:15,16 dan 18 Yesus berpesan kepada petrus untuk menggembalakan domba-dombaNya. ${ }^{7}$ Seorang gembala/pendeta adalah sebuah tugas khusus yang diberikan oleh Allah dan tidak hanya menjadi penggembala tetapi membimbing jemaat baik dalam kesusahan pun dalam kekurangan, serta memberikan motifasi dan prilaku hidup yang baik.

\section{Persepsi Jemaat Terhadap Gaya Hidup pendeta}

Persepsi adalah pemahaman atau penafsiran sesuatu, baik itu sesuatu yang di dengar ,dilihat, dirasa, dst. Persepsi dapat di katakan bahwa suatu informasi yang belum tentu kebenarannya tetapi ada kalanya juga benar, tergantung dari persepsi apa yang di terima. Persepsi merupakan hal yang sering di alami oleh setiap orang. Bahkan bisa di katakn selalu muncul baik di dalam kehidupan ataupun dalam pikiran setiap orang. Untuk menimbulkan sebua informasi atau terkadang juga memberikan fitnah kepada seseorang. tetapi ada juga yang memberikan dampak baik pada seseorang untuk mengubah pola pikir menjadi lebih baik. Persepsi muncul akibat ada kecurigaan terhadap seseorang, entah itu teman, pasangan, bahkan orang terdekat kita sekalipun. Dan tak terkecuali persepsi kepada orang-orang yang

\footnotetext{
${ }^{5}$ Ibid, hlm 19

${ }^{6}$ Ibid, hlm 23

${ }^{7}$ Prof. Dr. M. Bons-Strom, “Apakah Penggembalaan Itu”?, Gunung Mulia; Jakarta, 2004. Halm 2
} 
dianggap suci atau jauh dari perbuatan-perbuatan yang tidak baik. Misalnya jemaat yang menimbulkan persepsi terhadap pendetanya sendiri.

Jemaat adalah sekumpulan orang-orang percaya. Jemaat dapat juga diartikan sebagai Gereja. Istilah ini berasal dari bahasa Yunani kuno yaitu Ekklesia dalam bahsa latin ecclesia yang berarti jemaat, gereja. Gereja juga merupakan perkumpulan orang percaya, yang bersama-sama beribadah di dalam nama Tuhan Yesus Kristus yang bertugas untuk memebawa orang-orang yang belum berada di dalam terang menuju pada terang Tuhan. atau percaya kepada Yesus sebagai Tuhan dan Juruslamat. ${ }^{8}$

Setiap orang pasti ada saja kecurigaan terhadap seseorang yang mungkin tak asing berbuat sesuatu yang tidak benar. apalagi dilauar hal yang seharusnya dia tidak lakukan ia lakukan. Hal inilah yang terkadang menimbulkan persepsi seseorang. Hal yang tak asing membuat seseorang menimbulkan pesepsi adalah seorang pendeta dalam gaya hidupnya tidak sesuai dengan cerminan prilaku seorang pendeta. Meskipun dalam kesehariannya ikut di dalam pelayanan tetapi tak kala ia tidak mencerminkan prilaku seorang pendeta. Bagaimana biasa dikatakan tidak mencerminkan prilaku seorang pendeta? Dikatakan tidak mencerminkan prilaku seorang pendeta ketika di dalam kehidupannya tidak berbuat sesuai dengan apa yang diharapkan jemaat. Seperti apa yang di harapkan jemaat? Ketika pendeta hidup dengan damai dengan jemaat, tidak menjadi batu sandungan saja dalam jemaat. Ketika seorang pendeta kerjaannya hanya minum-minuman keras dan perokok. Hal ini kan tidak lagi diharapkan jemaat dan ini juga tidak sepantasnya dilakukan seorang pendeta.

\section{Hal Yang Harus Dilakukan dan Yang Harus Dijauhi Seorang Gembala/Pendeta}

Seperti telah di jelaskan sebelumnya bahwa seorang pendeta/gembala adalah orang suci dan orang yang memiliki hubungan khusus dengan Allah sekaligus menjadi pemberita Firman Allah kepada umatNya atau sebagai perantara. dan memberi jalan yang benar kepada umat Allah. sehingga ada hal-hal yang harus di hidari dan yang harus dilakukan oleh seorang pendeta untuk tidak menimbulkan persepsi buruk dari jemaat. Sehingga dapat memberikan cerminan baik juga kepada jemaat. Di dalam 1 kor. 6:19-20 dikatakan bahwa tubuh ini adalah bait Roh Kudus yang di di dalam kita. Sehingga tidak dapat dicemari oleh hal-hal yang tidak baik. Seperti minuman keras, rokok dst. dan hal ini tidak pantas dilakukan oleh seorang

\footnotetext{
${ }^{8}$ Hery Susanto. “Gereja Yang Berfokus Pada Gerakan Misioner". JURNAL FIDEI: Vol 2 no. 1, 2019. Hal 6364
} 
pendeta atau gembala. Bukannya memberikan dampak atau contoh yang baik pada jemaat mala memberi dampak buruk. Sehingga pendeta di tuntut untuk memberikan perilaku/contoh yang baik guna tidak menimbulkan persepsi atau kecuriagaan jemaatnya.

\section{Kesimpulan}

1. Pendeta adalah perantara Allah dengan umatnya sehingga dituntut untuk bisa memberikan contoh yang baik untuk bisa memberi dampak baik pada jemaat

2. Persepsi seseorang dapat timbul ketika sesautu yang tidak diharapkan terjadi pada seseorang. Sehingga terjadi kecurigaan yang bisa bersifat opini tetapi juga bisa bersifat nyata.

3. Sikap atau gaya hidup pendeta yang buruk akan mengakibtakan pelayanan di dalam jemaat tidak maksumal

\section{Referensi}

1. Haryono, T, and Daniel Fajar Panuntun. "Model Gaya Hidup Nazir Sebagai Refleksi Gaya Hidup Hedon Pengkotbah Pada Zaman Milenial.” Evangelikal: Jurnal Teologi Injili dan Pembinaan Warga Jemaat3, no. 2 (2019).

2. Prof. Dr. M. Bons-Strom, “Apakah Penggembalaan Itu”?, Gunung Mulia; Jakarta, 2004.

3. Efi Nurwindayani and Daniel Fajar Panuntun, "Pengaruh Saat Teduh Dan Ibadah Terhadap Pengambilan Keputusan Dalam Memilih Pasangan Hidup, ” FIDEI: Jurnal Teologi Sistematika Dan Praktika 2, no. 2 (2019)

4. Robert P. Borrong, "Melayani Makin Sungguh”, Cet.-1; Gunung Mulia: Jakarta, 2016

5. Hery Susanto. “Gereja Yang Berfokus Pada Gerakan Misioner". JURNAL FIDEI: Vol 2 no. 1, 2019

6. Ronald W. Leigh. “Melayani dengan Efektif”. Gunung Mulia: Jakarta, 2012 